\title{
The Influence of Interactive Powerpoint Multimedia in Social Studies Learning on Concept Understanding of Students`Social Mobility
}

\author{
Gita Kartika Dwirahayu' ${ }^{1}$, Kokom Komalasari², Asep Mulyadi ${ }^{3}$ \\ Social Studies Education Study Program, Faculty of Social Sciences Education, \\ Indonesia, Universitas Pendidikan Indonesia
}

\begin{abstract}
One of the objectives of social studies is to recognize concepts related to people's lives and the environment. Social mobility is one of the material discussed in social studies learning and requires a more comprehensive understanding of students. One effort to improve the understanding of concepts in social studies learning is to use interactive multimedia PowerPoint. Through interactive multimedia PowerPoint, students are expected to be able to observe the concepts contained in learning material by absorbing as much information as possible through their senses so that they can improve the understanding of the concept of social mobility of students in social studies learning. The purpose of this study is to identify understanding of students' concepts when using interactive multimedia PowerPoint in social studies learning at Tasikmalaya $3^{\text {rd }}$ Junior High School. The research method used a quasi experimental method with a nonequivalent control group design design pattern. The subjects of this study were Tasikmalaya $3^{\text {rd }}$ Junior High School students there are class VIII B as the experimental class and class VIII C as the control class. The technique of collecting data is through tests of understanding the concepts of the pretest and posttest. Data analysis techniques using the normality test using chi square, homogeneity test using the Ftest, and hypothesis testing using the t-test. The results showed an increase in the experimental class gain score on the three indicators, there are translation, interpretation, and extrapolation were higher than the control class. So that it can be concluded, social studies learning by using interactive PowerPoint multimedia is more effective in improving students' concepts understanding.
\end{abstract}

Keywords: Interactive PowerPoint Multimedia, Concepts Understanding, Social Studies Learning Correspondence. gita.kartikad@gmail.com

Article History. Received January 2019, Received in revised March 2019, Accepted June 2019

C2019. International Journal Pedagogy of Social Studies. Department of Social Studies Education

\section{A. INTRODUCTION}

Concept understanding is one of the social studies learning objectives, meaning that the material taught to students is more than just memorizing. Sapriya (2007, p. 7) Social studies learning materials are prepared to refresh memories not to be memorized. In social studies learning many fields of study require students to have a conceptual understanding of each study of existing disciplines.

Understanding the concept is very important in learning because by understanding a concept in the future students will be able to apply the concepts that exist in everyday life, the importance of understanding the concept is also supported by the Curriculum Center which says that when understanding the concept of learning can be applied in daily life these days can encourage the achievement of social studies learning objectives themselves, namely to develop the potential of students to be sensitive to social problems that occur in the community, have a positive attitude towards all problems that occur and are skilled at overcoming all the problems that occur in everyday life.

The success of the social studies learning process is influenced by many components, according to Slameto (2010), including the objectives of education, students, educators, subject matter or material, approaches and methods, media or tools, learning resources, and evaluation. All components in the teaching system are interconnected and influence each other to achieve teaching goals. In this study, researchers focused on one component of 
social studies learning, namely the use of interesting learning media with learning material by the teacher.

Today, the development of technology has an influence on all aspects of life, one of which influences the aspect of education. In the aspect of technology education is applied in the learning process as a learning medium that has functions to help educators deliver learning messages, overcoming limitations of space and time and also to make learning more enjoyable.

Media according to Scramm 1977 in Rusman et al. (2012) is a messenger technology that can be used for learning purposes. There are types of media that can be used directly by the teacher in learning, meaning that the media is made by certain parties (media producers), as well as natural media available in the school environment, including those that can be directly used. In addition, we can also create our own media according to the abilities and students needs.

Multimedia-based learning according to Rusman, et al (2012, p. 60) is a learning activity that uses computers to create and combine text, graphics, audio, moving images (video animation) by combining links and tools that allow users to navigate, interact, create, and communicate. The purpose of this multimedia is to convey information in a form that is fun, interesting, easy to understand and clear. Information will be easy to understand because information is absorbed as much as possible through the senses, especially the ears and eyes. The form of computer use as multimedia that can be used in learning, one of which is the use of interactive multimedia.

Interactive multimedia according to Rusman, et al (2012, p. 67) is used to explain material that is theoretical, used in classical learning with a learning group that is quite a lot above 50 people. The advantage of this multimedia is that it combines several media elements such as text, video, animation, image, graphics and sound into one presentation, so that this program can accommodate students who have visual, auditive or kinesthetic types.

Use presentation design software such as Microsoft Power Point, which was developed by Microsoft Inc. Interactive Multimedia PowerPoint is chosen because interactive Multimedia PowerPoint consists of a combination of several media elements so that it can facilitate different types of student learning. In addition, interactive multimedia has interactive properties which means interactive Multimedia PowerPoint is two-way communication, learning will be active because students are given the opportunity to be involved in the learning process.

Social Studies learning is one of the subjects taught in Tasikmalaya 3rd Junior High School. One of the material discussed in social studies is material on social mobility. The process of learning social studies in Tasikmalaya $3^{\text {rd }}$ Junior High School still uses the lecture method. In social studies learning, the themes taught are mostly theoretical, so students need a long time to understand the concepts of these materials if only by using the lecture method.

If the teacher only uses the lecture method, it will lead to monotonous learning so that students feel bored. Furthermore, students' thinking will not develop far, in the sense that students are only limited to remembering but do not understand the concepts that exist in the material being taught and do not place themselves when educators tell a situation in the material of social mobility.

Based on the description above, the researcher was interested in conducting research on the effect of interactive powerpoint multimedia on the 
understanding of students' concepts of social mobility to find out differences before and after application of learning using interactive powerpoint multimedia.

\section{B. METHODS}

The research used in this study was a quasi-experimental method with the research design of Nonequivalent Control Group Design. In this design there are two groups selected randomly, then given the pratest to find out the initial situation and see the difference between the experimental group and the control group.

Experiment Class $\mathrm{O}_{1}-\mathrm{x}-\mathrm{O}_{2}$

$\overline{\text { Control Class } \quad \mathrm{O}_{1} \longrightarrow \mathrm{O}_{2}}$

The population in this study were eighth grade students of Tasikmalaya 3rd Junior High School. The sample in this study was class VIII B as an experimental class as many as 30 students and class VIII C students as a control class as many as 31 students.

The research technique used in this study is to use test techniques. The tests carried out by researchers included the Pretest and Posttest. Before conducting the test, the researcher tested the validity and reliability of the test items. Questions that are declared valid can be distributed to the research sample. After collecting data, the data is processed using homogeneity test and hypothesis testing using the SPSS 21 application.

In this study, a normality test was carried out to find out the data on student motivation that was normally distributed. And also the homogeneity test that is the test of the nature of the data whose purpose is to find out whether or not homogeneity of data variations.

The last analysis technique is hypothesis testing which aims to determine whether or not the research hypothesis is accepted by the following criteria:

1) If the probability (sig.) $>0.05$, then Ho is accepted. This means that there is no significant difference in the ability to understand students' social mobility concepts before being given treatment and after being given treatment with interactive multimedia PowerPoint.

2) If the probability (sig.) $<0.05$, then Ho is rejected. This means that there is a significant difference in the ability to understand students' social mobility concepts before being given treatment and after being given treatment with interactive multimedia PowerPoint.

\section{RESULTS AND DISCUSSION}

The essence of the discussion in this section is to describe the results of the study in looking at the understanding of the concept of social mobility of students before and after the implementation of research by applying interactive powerpoint learning media in the experimental class and conventional media in the control class.

Based on the results of the data if the statistics in the normality test show the value of the results of the significance of the pretest and posttest in the experimental class and the control class greater than 0.05 . So that it can be said that the results of the data from the experimental class and the control class can be said to be normal.

Then when viewed from the homogeneity test value shows a significant value of more than 0.5 which means $\mathrm{Ha}$ is accepted and Ho is rejected. So that it can be said that the pretest data in the experimental and control classes have a homogeneous population variance.

The results of the study can be seen from the results of the discussion below: 
1. The significant difference in understanding the concept of student social mobility between the experimental class and the control class.

Based on the results of the analysis even though the students in both classes experienced an increase in the ability to understand the concept, the experimental class improved the ability to understand the concept with learning assisted by multimedia learning interactive PowerPoint greater than the control class that only used conventional media.

Graph 1. Differences in Average Conceptual Understanding of Experimental Class Students (VIII-B) and Control Classes (VIIIC)

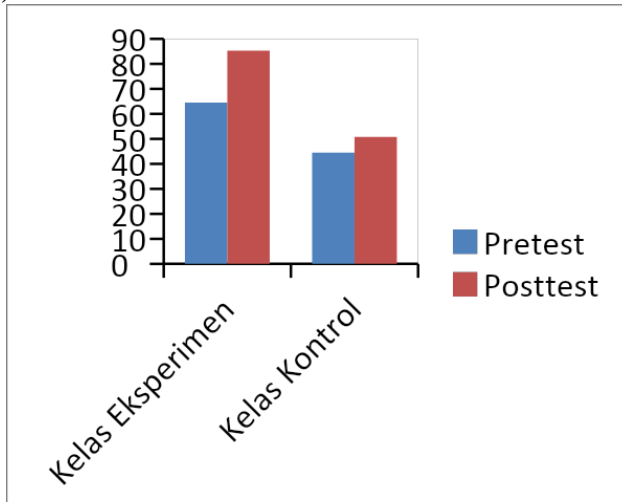

Source: Researcher (2018)

Before being given treatment, the average ability to understand the concept in the experimental class was 64.5 but after being given treatment by using interactive multimedia multimedia learning media the average learning outcomes increased to 85.3 or an increase of $32 \%$. While in the control class the average ability to understand the concepts of students before being given a learning treatment using conventional learning media is 44.5 . Then the average value after being given treatment is 50.8. The ability to understand concepts in the control class increased by $14 \%$. Thus it can be concluded that there is a significant difference in understanding the concept of students' social mobility between the experimental class and the control class.

This is in line with the opinion of Rusman et al. (2012, p. 295-296) explaining that when viewed from learning rules, increasing the cognitive level of students in this case is a high understanding of students' concepts, strongly supported by the use of learning media. Through the medium of sensory potential students can be accommodated so that the level of understanding of students' concepts will increase. One aspect of the media that is superior is able to improve understanding of the concept is multimedia, namely a combination of various media elements such as text, images, animations, videos.

Based on the results of research on the use of multimedia, information / teaching material through text can be remembered well if accompanied by pictures. This is explained by dual coding theory Paivio, (1986). According to this theory, the human cognitive system consists of two subsystems, namely the verbal system and the image system (visual). So the presence of images in text can increase memory because of the presence of dual coding in memory.

In addition to the existence of images and text, in multimedia learning there are also elements of video that can help learning optimally. as previously examined by Rubianti et al (2017) states that with video media, students can think flexibly, besides students can also easily understand the material and also through video, students can communicate the ideas contained in the video.

This interactive PowerPoint has advantages, one of which is interactive. According to Bambang (2008, pp. 155156) the interactive nature of interactive multimedia can create two-way 
communication, meaning that this program provides opportunities for students to respond, and stimulates students to carry out various learning activities so that learning will be more active .

\section{The application of effective} interactive multimedia PowerPoint to the understanding of the concept of social mobility of students in social studies in the experimental class

On the results of the pretest and posttest the ability to understand the concept of experimental class students in class VIII-B in social studies learning material on social mobility using interactive multimedia PowerPoint learning media can be seen in the following graph;

Graph 2. Pretest and Posttest Results Ability to Understand Concepts of Experimental Group Students (VIII-B)

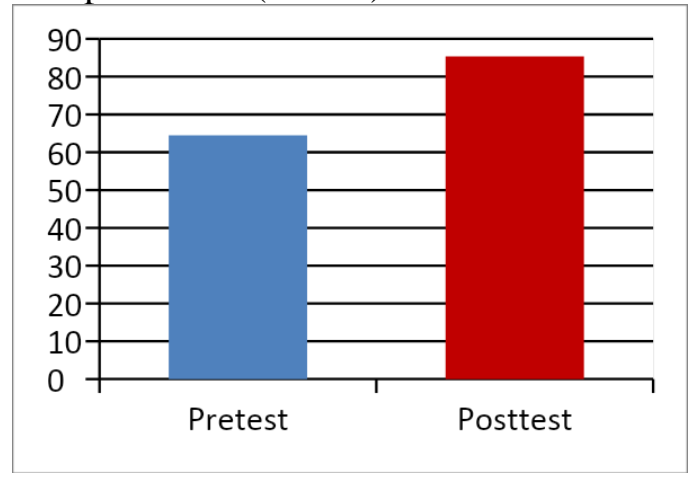

Based on the graph above can be seen the average ability of students' understanding of concepts when the experimental class pretest of 64.5 this shows the initial ability to understand the concept of students regarding social mobility is still low because students have not learned it. Seen in the execution of the pretest students still guess the answer. After being given treatment with learning using interactive Powerpoint multimedia learning media, the students' ability to understand concepts improved with an average posttest score of 85.3 with an increase of $32 \%$. This can happen because before the final test the students have been given treatment with the help of interactive PowerPoint PowerPoint learning media so that they can answer the questions in the posttest based on the knowledge gained during the treatment.

In addition, based on the results of data analysis through t-test (paired samples test) using SPSS, there is a significant difference in the value of sig. (2-tailed) $0.027<0.05$ or $\mathrm{H} 0$ is rejected, which means that there is a difference in understanding students' concepts when given treatment by using interactive PowerPoint multimedia after being given treatment using interactive multimedia PowerPoint. This means that interactive multimedia PowerPoint is effective in increasing the understanding of the concept of social mobility of students in social studies.

This is in line with the theory of "Quantum Learning" which states that students have different learning modalities which are divided into three types, there are visual, auditive, and kinesthetic. The diversity of modalities possessed by these students can be overcome by using media with multimedia systems, because each student with different types of learning can be represented by multimedia.

The results of research that have been studied by Fenrianti (2016) state that using media in learning can make learning more attractive and help students to be more focused and remember learning material.

The results of this study are in line with previous researchers conducted by Vicky Taniady et al. entitled "The Effect of Using Audio Visual Media on Understanding Concepts of Learners in Geography Learning" Based on the results of these studies it can be seen that 
there is a significant difference between learning using audio visual with learning without using audio visual on understanding concepts at Labschool High School UPI Bandung. This happens because the use of audio visual media is far more effective in building understanding of students' concepts through the help of audio as well as visual elements.

Each learning media certainly has its own advantages and disadvantages and requires adjustment when applied in the field, but with interactive multimedia PowerPoint students are expected to be able to understand the concepts in social studies learning material. Not only that, with interactive multimedia PowerPoints it is also expected to be able to realize increased learning outcomes, learning motivation, active student learning in the classroom in social studies learning.

\section{CONCLUSION}

There are differences in the ability to understand the concept of experimental class students and control classes can be seen from the average value of the pretest and posttest of students. In the pretest activity, the average score of students in the experimental class was 64.5. As for the posttest activities the average value of students increased to 85.3. So the average student score increased by $32 \%$. Meanwhile, in the comparison class (control) the difference in students' conceptual comprehension ability at the pretest value of the student average was 44.5. Whereas in the posttest activity the average score of students increased to 50.8. Thus the average value of students increased by $14 \%$.

\section{E. AKNOWLEDGEMENT}

To the Social Sciences Education Study Program, Faculty of Social Sciences Education, University of Education Indonesia for the publication of this article in the journal Social Studies Education Study Program.

\section{REFERENCES}

Arsyad, A. (2015). Media Pembelajaran. Jakarta: Rajawali Pers.

Sapriya. (2007). Konsep Dasar IPS. Bandung: Lab Pkn UPI.

Sapriya. (2009). Pendidikan IPS Konsep dan Pembelajaran . Bandung: Remaja Posdakarya.

Slameto. (2008). Proses Belajar Mengajar. Jakarta: Remaja Rosdakarya.

Rusman, \& dkk. (2012). Pembelajaran Berbasis Teknologi Informasi dan Komunikasi. Jakarta: Rajawali Pers.

Rusman. (2012). Belajar dan Pembelajaran Berbasis Komputer, Mengembangkan Profesionalisme Abad 21. Bandung: Alfabeta.

Taniady, Vicky, dkk (2016). Pengaruh Penggunaan Media Audio Visual Terhadap Pemahaman Konsep Peserta Didik dalam Pembelajaran urnal Geografi. Vol 16, no 2. [diakses di ejournal.upi.edu/index.php/gea/arti cle/view/5231

Rubianti, Teni Dwi, dkk (2017). Media Application Feature Video Creative thinking Ability to Improve the Students in Learning IPSA. Vol 2, No 1.

Febrianti, Putri Laras (2016). Effectifity of VCT Method in Teaching Social Sciences to Improve the Mental Attitude Of Manners. Vol. 1, No. 2. 